\title{
Effects of Three Different Lighting Programs on Live Weight Change of Bronze Turkeys under Semi-Intensive Conditions
}

\begin{abstract}
A study was conducted to evaluate the influence of three lighting programs (23L: 1D), (18L: 6D), and (12L: 12D) on live weight changes of American Bronze turkeys by Profile analysis technique. The F-statistics and Wilk's Lamba statistics for testing group-response interaction or similar profiles suggested that there was a significant interaction effect $(\mathrm{p}<0.01)$. The effects of the three lighting programs on live weight gain appeared to be different throughout the study except for the last 6 weeks. On the other hand, the results of the present study suggested that the effect of the three lighting programs on live weight gain followed a similar trend or three lighting programs had similar physiological effect on live weight gain from $10^{\text {th }}$ week on wards.
\end{abstract}

Key Words: American Bronze turkey, live weight, lighting regime, profile analysis, repeated measurement

\section{Zusammenfassung}

Titel der Arbeit: Einfluss von drei unterschiedlichen Beleuchtungsprogrammen auf die Lebendgewichtsveränderung von Bronzeputen unter semi-intensiven Bedingungen

Die vorliegende Arbeit wurde mit Hilfe des Profilanalyseverfahrens durchgeführt, um den Einfluss von 3 unterschiedlichen Beleuchtungsprogrammen (23L:1D, 18L:6D und 12L:12D) auf das Lebendgewicht amerikanischer Bronzeputen zu bewerten. Die Ergebnisse der F-Statistik und der Wilk's Lamba Statistik zeigen eine signifikante Gruppen-Effekt-Interaktion $(\mathrm{p}<0,01)$. Die Effekte der unterschiedlichen Lichtprogramme auf die Zunahme des Lebendgewichts zeigten, mit Ausnahme der letzten 6 Wochen, unterschiedliche Einflüsse. Allerdings muss hervorgehoben werden, dass die Lebendgewichtszunahme ab der 10. Woche unter allen Lichtprogrammen einer ähnlichen Tendenz folgte bzw. die physiologischen Einflüsse während dieser Phase der Aufzucht offensichtlich sehr ähnlich sind.

Schlüsselwörter: Amerikanische Bronzeputen, Lebendgewicht, Beleuchtungsprogramme, Profileanalyse, wiederholte Messung

\section{Introduction}

Lighting is one of the most crucial environmental factors which affects poultry performance. An increase in lighting period also increases time for feeding. Therefore, continuous lighting is applied in fattening. On the other hand any reduction in lighting period leads to slow growth. Continuous or intermittent lighting in fattening affects not only growth rate and performance of poultry but also carcass quality (CLASSEN et al., 1991; LILBURN et al., 1992; CLARKE et al., 1993; HAMILTON and KENNIE, 1997).

Live weight gain is one of the most important performance criteria, so determination of effects of lighting programs and periods is of particular importance in poultry production (NOLL et al., 1991; HERSTAD, 1992; MORRIS and BUTLER, 1995). Comparison of effect of different lighting programs on weight gain is a crucial step in deciding the best management system which will provide maximum economic benefit to the producer. Proper lighting program should be determined since the live weight of 
turkey varies according to the lighting program applied. Many studies have been carried out to determine the effect of different lighting systems on live weight gain and growth performance in poultry production (BUCKLAND et al., 1976; SIOPES et al., 1986; CECIL, 1986; HESTER et al., 1987; KOVACHISHKI et al., 1987; LEWIS and PERRY, 1990; AL-MAHROUS, 1997; YAHAV et al., 2000). However, convincing results have not been always obtained from these studies due to the aim of the study or the choice of the statistical methods in the evaluation of the data. The aim of this study was to investigate the effects of three different lighting programs on weekly body weight gain of bronze turkeys by Profile analysis, which is an extension of the repeated measurement and provides rather specific information in comparison to repeated measurement and growth curve models (GRIBSKO, 1987; MORRISON, 1995; RENCHER, 1995; DING, 2001; SUMMERS et al., 2001), to obtain more detailed information.

\section{Materials and Methods}

In this study, 15 week old 60 male American Bronze turkeys were used. The study was carried out at the Research Unit of Çanakkale Onsekiz Mart University.

The animals were raised under intensive condition with a lighting program of 23D:1D in the first 55 days of the study. They were then allowed to go onto the pasture till the end of the study. Three different artificial lighting programs in addition to day light were applied $16^{\text {th }}$ week onwards. Therefore, $16^{\text {th }}$ week was taken as the first week of the study for three different lighting programs. I. group (control), II. group and III. group involved lighting programs of 23L:1D, 18L:6D and 12L:12D, respectively. Each group had 20 turkeys. The live weight gains of turkeys in all groups were determined by weighing and the animals were slaughtered at $31^{\text {st }}$ week of the study.

The starter and growth diets of the animals included 28\% crude protein, 2900-3000 $\mathrm{kcal} / \mathrm{ME}$ and $22 \%$ crude protein, $2800-2900 \mathrm{kcal} / \mathrm{ME}$, respectively under intensive condition. Wheat and water were offered ad libitum to the turkeys when they returned back from the pasture under semi-intensive condition.

\section{Statistical Method}

In this study, k-sample profile analysis was adapted to compare live body weights of groups of American Bronze turkeys. This allowed for the assigment of a level of statistical significant differences and the shapes of the centroids of three lighting programs. Profile analysis is a method of comparison of groups that are experimental units to the same set of $p$ measurements by examining the $p-1$ slopes between adjacent coordinate values for mean vectors of the groups. Profile analysis is an extension of the repeated measurement.

The basic of profile analysis is a sequence comparison method for finding and aligning distantly related sequences.

Let $\mu_{\mathrm{i}}=\left(\mu_{\mathrm{i} 1}, \mu_{\mathrm{i} 2, \ldots}, \mu_{\mathrm{ip}}\right)$ be the mean vector for group $\mathrm{i}$ and the subjects of this vector representing the avarage responses to the $\mathrm{p}$ measurements. It is known that the test for no treatment effect is equivalent to $\mathrm{H}_{0}: \mu_{1}=\ldots=\mu_{\mathrm{j}}$. Rather than testing the hypothesis that $\mathrm{H}_{0}: \mu_{1}=\ldots=\mu_{\mathrm{j}}$, we wish to be more specific in comparing the profiles obtained by connecting the points $\left(i, \mu \mathrm{j}_{\mathrm{i}}\right),\left(\mathrm{i}, \mu \mathrm{j}_{\mathrm{i}}\right), \ldots,\left(\mathrm{i}, \mu \mathrm{j}_{\mathrm{i}}\right), \mathrm{i}=1,2, \ldots, p$ and $\mathrm{j}=1,2, \ldots, \mathrm{k}$. 
There are three different hypotheses of interest in comparing the profiles of two or more samples as follows:

a) The population mean profiles are parallel or there is no treatment $\mathrm{x}$ repeated factor interaction effect.

b) If the first hypothesis is true (the population profiles are parallel), are they also at the same level? That is, $\mathrm{k}$ profiles are all at the same level or there is no treatment effect.

c) Again assuming parallelism, are the population means of the tests different? That is, the means of all $p$ variables in each group are the same.

The first hypothesis refers to the hypothesis of no response by group interaction, while the second hypothesis refers to the hypothesis of equal group effect and the third hypothesis refers to the hypothesis of repeated factor effect or response effect. The tests for equal levels and response effects have no meaning If a group-response interaction is present. The parallelisim hypothesis can be defined with respect to the slopes. The profiles are parallel if the two slopes for each segment are the same. Therefore, if the profiles are parallel or there is no interaction effect, the increments for each segment are the same and it is not necessary to use actual slopes to express the hypothesis, since we simply compare the increase from one point to the next. This is one of the superiority of profile analysis to other methods such as repeated measurements and growth curve (SRIVASTAVA and CARTER, 1983; MORRISON, 1995).

The hypothesis of parallelism can be expressed as $\mathrm{H}_{0}: \mathrm{C} \mu_{1}=\mathrm{C}_{2}=\ldots=\mathrm{C}_{\mathrm{k}}$

The hypothesis (3) is equivalent to the null hypothesis $\mathrm{H}_{0}: \mu_{\mathrm{z} 1}=\mu_{\mathrm{z} 2} \ldots=\mu_{\mathrm{zk}}$ in a oneway MANOVA on transformed variables $\mathrm{z}_{\mathrm{ij}}=\mathrm{Cy}_{\mathrm{ij}}$.

$\mathrm{z}_{\mathrm{ij}}$ is distributed as $\mathrm{N}_{\mathrm{p}-1}\left(\mathrm{C} \mu_{1}, \mathrm{C} \Sigma \mathrm{C}^{\prime}\right)$. Since $\mathrm{C}$ has $\mathrm{p}-1$ rows, $C y_{\mathrm{ij}}$ is $(\mathrm{p}-1) \mathrm{x} 1, \mathrm{C} \mu_{\mathrm{i}}$ is $(\mathrm{p}$ 1) $x 1$, and $C \sum C^{\prime}$ is $(p-1) \times(p-1)$.

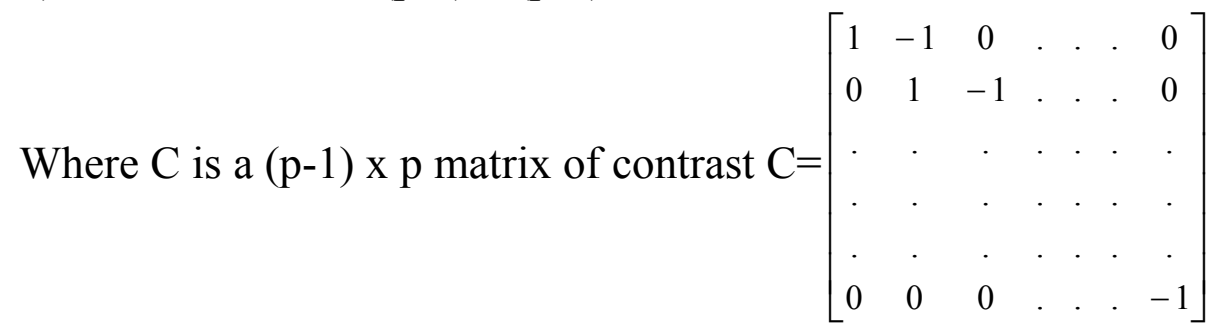

The hypothesis and error matrices for testing $\mathrm{H}_{0}: \mathrm{C}_{1}=\mathrm{C}_{2}=\ldots=\mathrm{C}_{\mathrm{k}}$ in (3) are $\mathrm{H}_{\mathrm{z}}=\mathrm{CHC}^{\prime}$ and $\mathrm{E}_{\mathrm{z}}=\mathrm{CEC} C^{\prime}$. We thus have

$$
\Lambda=\frac{|C E C|^{\prime}}{\left|C E C+C H C^{\prime}\right|}
$$

which is distributed as $\Lambda_{p-1}, v_{H}, v_{E}$.

Where $v_{H}=(\mathrm{k}-1)$ and $v_{E}=\mathrm{k}(\mathrm{n}-1)$. These calculations were based on those of RENCHER (1995). 


\section{Results}

Descriptive statistics, test of fixed effects, and results of Scheffe multiple comparisons are given in Table 1, Table 2 and Table 3, respectively. The effect of lighting programs on live weight gain in the first 10 weeks of the study was found significant $(p<0.05)$. However, lighting programs had no significant effect on live weight gain at the end of the 16 week study $(\mathrm{p}=0.11)$. The F-statistics and Wilk's Lamba statistics for testing group-response interaction or similar profiles, have the value of 4.36 and 0.21374 , respectively. Hence one concludes that there is a significant interaction effect $(p<0.01$, Table 2). In other words, the difference in mean live weights of the turkeys between weeks depends on lighting program (profiles are not parallel). Figure 1 and Figure 2 tend to support this conclusion. When the effect of lighting programs on total feed intake was evaluated, it was found that there was no difference between 23L:1D and 18L:6D lighting programs, but these two programs differed significantly from the 12L:12D lighting program $(\mathrm{p}<0.01)$.

Table 1

Descriptive statistics by groups (g) (Beschreibende Statistik der Gruppen (g))

\begin{tabular}{cccc}
\hline Weeks & $\begin{array}{c}\text { Group-I }(23 \mathrm{~L}: 1 \mathrm{D}) \\
\text { Mean } \pm \text { SE }\end{array}$ & $\begin{array}{c}\text { Group-II }(18 \mathrm{~L}: 6 \mathrm{D}) \\
\text { Mean } \pm \text { SE }\end{array}$ & $\begin{array}{c}\text { Group-III (12L:12D) } \\
\text { Mean } \pm \text { SE }\end{array}$ \\
\hline 1 & $3466.3 \pm 63.5$ & $3472.8 \pm 83.4$ & $3359.3 \pm 86.0$ \\
2 & $3712.0 \pm 77.4$ & $3688.0 \pm 90.8$ & $3498.3 \pm 89.6$ \\
3 & $3884.0 \pm 79.5$ & $3897.0 \pm 92.7$ & $3680.5 \pm 88.9$ \\
4 & $4188.0 \pm 83.0$ & $4146.0 \pm 106$ & $3858.4 \pm 97.4$ \\
5 & $4419.3 \pm 79.6$ & $4459.0 \pm 108$ & $4090.8 \pm 97.7$ \\
6 & $4528.5 \pm 93.4$ & $4648.0 \pm 122$ & $4279.0 \pm 104$ \\
7 & $4861.0 \pm 96.7$ & $4953.0 \pm 130$ & $4440.0 \pm 112$ \\
8 & $5148.8 \pm 95.0$ & $5214.0 \pm 131$ & $4739.0 \pm 128$ \\
9 & $5447.0 \pm 106$ & $5452.0 \pm 137$ & $5018.0 \pm 133$ \\
10 & $5688.0 \pm 111$ & $5801.0 \pm 142$ & $5294.0 \pm 140$ \\
11 & $6048.0 \pm 123$ & $6236.0 \pm 148$ & $5701.0 \pm 145$ \\
12 & $6324.0 \pm 138$ & $6463.0 \pm 169$ & $6022.0 \pm 155$ \\
13 & $6535.0 \pm 166$ & $6695.0 \pm 167$ & $6340.0 \pm 169$ \\
14 & $6958.0 \pm 171$ & $7102.0 \pm 188$ & $6782.0 \pm 174$ \\
15 & $7301.0 \pm 198$ & $7421.0 \pm 218$ & $7145.0 \pm 193$ \\
16 & $7654.0 \pm 211$ & $7828.0 \pm 255$ & $7547.0 \pm 219$ \\
\hline
\end{tabular}

Table 2

Tests of Fixed effects (Testergebnisse der fixen Effekte)

\begin{tabular}{lccc}
\hline & & Type 3 Tests of Fixed Effects & P \\
\hline Effect & F Value & Wilks' Lambda & 0.11 \\
Week & 2.30 & 0.10550 & 0.00 \\
Group*Week & 259.33 & 0.01394 & 0.00 \\
\hline
\end{tabular}

A profile plot of these means is given in Figure 1. There is a high degree of parallesim in the three profiles. The effects of these three lighting programs on live weight gain appeared to be different throughout the study except for the last 6 weeks. In other word, as the age of turkey increased, the difference in mean live weights decreased (Figures 1 and 2). The results of the Scheffe multiple comparison test support this finding statistically and so does Figure 2 visually.

When three lighting programs were compared in terms of the difference between consecutive weeks or profile segments (regression slopes), a significant difference at least between two lighting programs was found from the difference between live weigh means of 1-2, 3-4, 4-5, 5-6, 6-7, and 9-10 weeks. In fact, the effect of these 
three lighting programs on live weight gain was not at the same level. On the other hand, from $10^{\text {th }}$ week on wards, it can be said that the effect of the three lighting programs on live weight gain followed a similar trend. This can be seen from Figure 1 and 2. The differences between live weight means in consecutive weeks after $10^{\text {th }}$ week were parallel in three lighting programs (Table 3, Figures 1 and 2).

Table 3.

Differences among the groups for different weeks (g) (Differenzen zwischen den Gruppen während verschiedener Wochen)

\begin{tabular}{|c|c|c|c|c|}
\hline $\begin{array}{c}\text { Sequential week } \\
\text { difference }\end{array}$ & $\begin{array}{c}\text { Group1 } \\
\text { (23L:1D) }\end{array}$ & $\begin{array}{c}\text { Group2 } \\
\text { (18L: 6D) }\end{array}$ & $\begin{array}{c}\text { Group3 } \\
\text { (12L:12D) }\end{array}$ & Conclusion \\
\hline $1-2$ & $245.7^{\mathrm{a}}$ & $215.2^{\mathrm{a}}$ & $139^{\mathrm{b}}$ & significant \\
\hline $2-3$ & $172 \mathrm{a}^{\mathrm{b}}$ & $209^{\mathrm{a}}$ & $182.2^{\mathrm{ab}}$ & non-significant \\
\hline $3-4$ & $304^{\mathrm{a}}$ & $249^{b}$ & $177.9^{\mathrm{c}}$ & significant \\
\hline $4-5$ & $231.3^{b}$ & $313^{\mathrm{a}}$ & $232.4^{\mathrm{b}}$ & significant \\
\hline $5-6$ & $109.2^{\mathrm{b}}$ & $189^{\mathrm{a}}$ & $188.2^{\mathrm{a}}$ & significant \\
\hline $6-7$ & $332.5^{\mathrm{a}}$ & $305^{\mathrm{a}}$ & $161^{\mathrm{b}}$ & significant \\
\hline $7-8$ & $287.8^{\mathrm{a}}$ & $261^{\mathrm{a}}$ & $299^{\mathrm{a}}$ & non-significant \\
\hline $8-9$ & $298.2^{\mathrm{a}}$ & $238^{\mathrm{a}}$ & $279^{\mathrm{a}}$ & non-significant \\
\hline $9-10$ & $241^{\mathrm{b}}$ & $349^{\mathrm{a}}$ & $276^{b}$ & significant \\
\hline $10-11$ & $360^{\mathrm{a}}$ & $435^{\mathrm{a}}$ & $407^{\mathrm{a}}$ & non-significant \\
\hline $11-12$ & $276^{\mathrm{a}}$ & $227^{\mathrm{a}}$ & $321^{\mathrm{a}}$ & non-significant \\
\hline $12-13$ & $211^{\mathrm{a}}$ & $232^{\mathrm{a}}$ & $318^{\mathrm{a}}$ & non-significant \\
\hline $13-14$ & $423^{\mathrm{a}}$ & $407^{\mathrm{a}}$ & $442^{\mathrm{a}}$ & non-significant \\
\hline $14-15$ & $343^{\mathrm{a}}$ & $319^{\mathrm{a}}$ & $363^{\mathrm{a}}$ & non-significant \\
\hline $15-16$ & $353^{\mathrm{a}}$ & $407^{\mathrm{a}}$ & $402^{\mathrm{a}}$ & non-significant \\
\hline Grand mean $\pm \mathrm{SE}$ & $279.2 \pm 20.8^{\mathrm{a}}$ & $290.2 \pm 20.5^{\mathrm{a}}$ & $279.2 \pm 25.1^{\mathrm{a}}$ & non-significant \\
\hline
\end{tabular}

Table 4

Total live weight gains of turkeys of three lighting programs in the first 10 weeks and in the last 6 weeks of the study (g) (Totale Lebensgewichtszunahmen der Puten bei drei Lichtprogrammen in den ersten 10 Wochen und in den letzen 6 Wochen)

\begin{tabular}{lcc}
\hline Lighting Programs & Total live weight in the first 10 weeks & Total live weight in the last 6 weeks \\
\hline 23L:1D & 45342.8 & 40820.0 \\
18L:6D & 45730.8 & 41745.0 \\
12L:12D & 42257.3 & 39537.0 \\
\hline
\end{tabular}

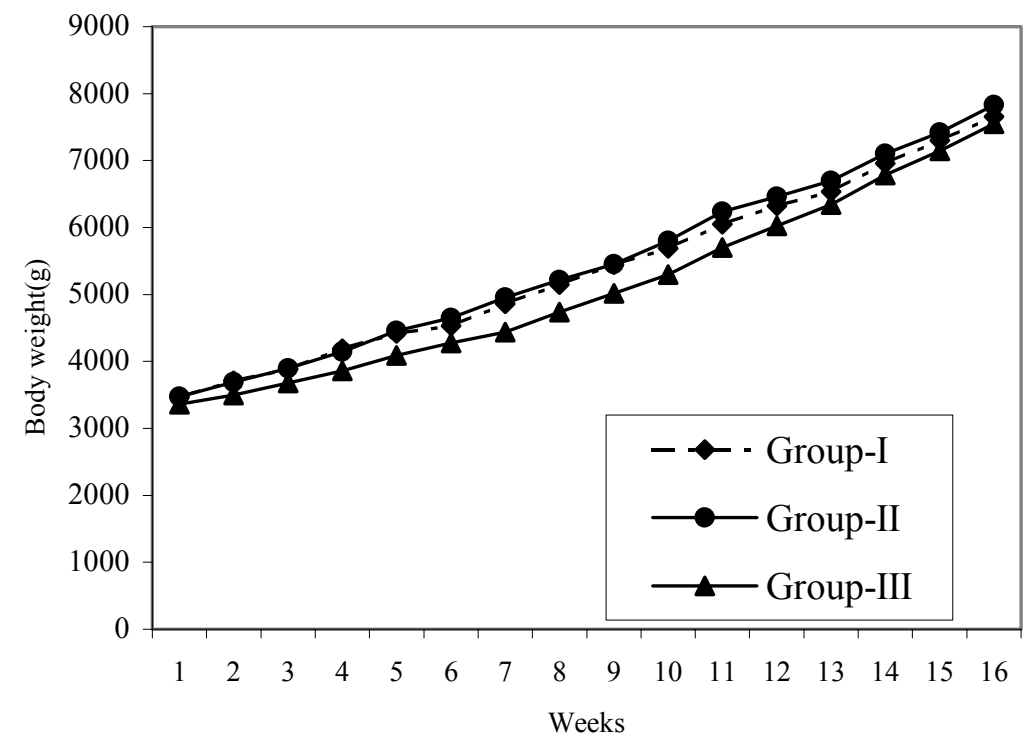

Fig. 1: Groups Profiles (Gruppenprofile) 


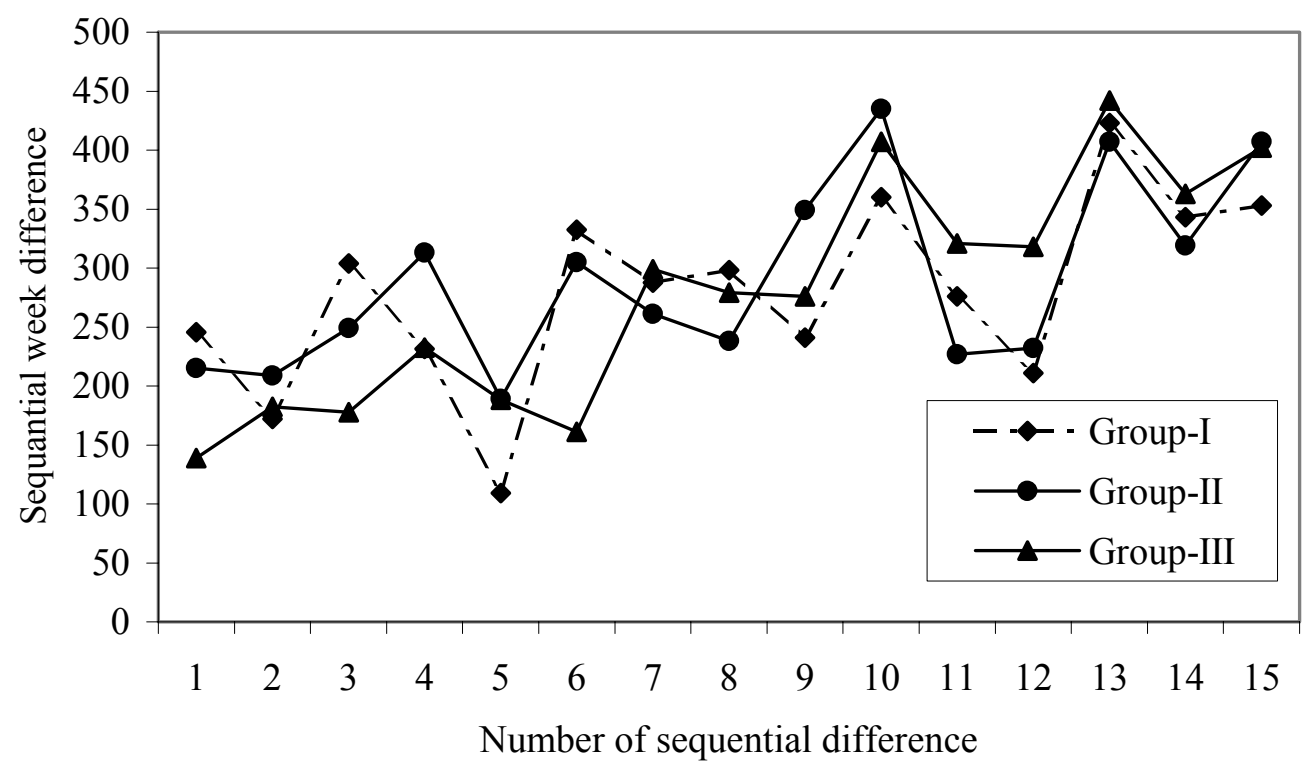

Fig. 2: Sequential week difference by groups (Verlauf der Differenzen der sequentiellen Wochen der Gruppen)

\section{Discussion}

The results of the present study indicated that differences in live weight gain and feed intake parameters among the three lighting programs were more apparent especially in the first 10 weeks of the study. The live weight gain and total feed intake of turkeys who were exposed to $23 \mathrm{~L}: 1 \mathrm{D}$ or $18 \mathrm{~L}: 6 \mathrm{D}$ were significantly higher in the first 10 weeks of the study as compared to the turkeys received a lighting program of 12L:12D. However, live weight gain and feed intake values of all the treatment groups tended to get similar after the $10^{\text {th }}$ week. In other words, from $10^{\text {th }}$ week onwards, the live weight gain and feed intake of turkeys increased as the feeding period increased. Total live weight of turkeys exposed to a lighting program for 23L:1D was $45342.6 \mathrm{~g}$, and were $45730 \mathrm{~g}$ and $42257.3 \mathrm{~g}$ for $18 \mathrm{~L}: 6 \mathrm{D}$ and $12 \mathrm{~L}: 12 \mathrm{D}$ at the end of 10 weeks. On the other hand, the same parameter was found to be $40820 \mathrm{~g}, 41745 \mathrm{~g}$ and $39537 \mathrm{~g}$ for 23L:1D, 18L:6D and 12L:12D groups, respectively in the last 6 weeks of the present study (Table 4). It is important to note that the highest weight gain occurred in the 18L:6D group, whereas the lowest weight gain was observed in the 12L:12D group in both the first 10 and the last 6 weeks of the study. The results of the feed intake of turkeys are similar to those of other studies in the literature (HALVORSOR et al., 1991; NOLL et al., 1991; CLARKE et al., 1993; SENGUL et al., 2000). On the other hand, maximum live weight difference among three lighting programs throughout first 10 weeks (3473.5 g) was notably higher than the weight gain (2208 g) observed throughout last 6 weeks. This suggests that the effects of lighting systems on weight gain and feed intake were rather similar to each other in the last 6 weeks of the present study. The feed intake of turkeys exposed to a lighting program of 12L:12D seemed to follow a compensatory pattern in which they increased their feed intake resulting in increased weight gain as compared to that of turkeys receiving a lighting program of 23L:1D and 18L:6D.

Though this finding is consistent with the results of HERSTAD (1992), NEWBERRY (1992), HULET et al. (1993), CLASSEN et al. (1994), HEMILTON and KENNIE 
(1997), SENGUL et al. (2000), and YAHAV et al. (2000), it provides other implications. In this regard, in addition to the trial conditions, the aim of studies and the use of statistical models for the evaluation of the results of such studies can have significant influence on the outcome of such studies. For example, SENGUL et al., (2000) investigated the effect of three different lighting programs on growth performance and carcass quality in American Bronze turkeys. They analyzed their data in a $3 \times 2$ factorial design and found a significant interaction between three lighting programs and live weight, but not between lighting program and week. In fact, the evaluation of the data of consecutive weeks can lead to disappearance of the effect between weeks and of the carry-over effect between consecutive weeks throughout the study. Therefore, the results of similar studies can be variable due to the use of various statistical models for data evaluation.

This finding indicates that the effect of lighting programs is rather crucial on the physiology of turkeys in the first 10 weeks. We can suggest that a lighting program of 18L:6D is more preferable than the other programs. However, it should be born in mind that the suitability of lighting program may depend on poultry species and other husbandry factors.

\section{References}

AL-MAHROUS, M:

Einfluss des Alters von Broilern bei Beginn eines Nachtlichtprogrammes auf die Mastleistung (Kurzmitteilung). Arch. Tierz., Dummerstorf 40 (1997), 159-164

BUCKLAND, R.B.; BERNON, D.E.; GOLDROSEN, A.:

Effects of four lighting regimes on broiler performance, leg abnormalities and plasma corticoid levels. Poultry Science, 55 (1976) 3, 1072-1076

CECIL, HC:

Effect of light intensity during the breeder period on semen production of low weight and normal weight breeder turkeys. Poultry Science, 65 (1986) 10, 1900-1904.

CLARKE, J.P.; FERKET, P.R.; ELKIN, R.G.; McDANIEL, C.D.; FREED, M.; McMURTRY, J.P.; KREUGER, K.K.; HESTER, P.Y.:

Early dietary protein restriction and intermitted lighting. II.Effects on carcass characteristics of male turkeys. Poultry Science, 72 (1993) 11, 2144-2151

CLASSEN, H.L.; RIDDELL, C.; ROBINSON, F.E.:

Effects of increasing photoperiod length on performance and health of broiler chickens. British Poultry Science, 32 (1991) 1, 21-29

CLASSEN, H.L.; RIDDELL, C.; ROBINSON, F.E.; SHAD, P.J.; McCURDY, A.R.:

Effect of lighting treatment on the productivity, health, behavior and sexual maturity of heavy male turkeys. British Poultry Science, 35 (1994) 2, 215-225

DING, CS.:

Profile analysis: multidimensional scaling approach. Practical Assessment, Research\&Evaluation, 7(16) (2001). http://edresearch.org/pare/getvn.asp? $=7 \& n=16$.

GRIBSKOV, M.; MCLACHLAN, A.D.; EISENBERG, D.:

Profile Analysis: Detection of Distantly Related Proteins. Proceedings of the National Academy of Sciences, 84 (1987), 4355-4358

HALVORSOR, J.C.; WAIBEL, P.E.; OJU, E.M.; NOLL, S.L.; EL-HALAWANI, ME.:

Effect of diet and population density on male turkeys under various environmental conditions. 2.body composition and meat yield. Poultry Science, 70 (1991) 4, 935-940

HAMILTON, R.M.G.; KENNIE, J.:

The effects of lighting program. Ingredient particle size and feed form on the performance of broiler turkey. Canadian Journal of Animal Science, 77 (1997) 3, 503-508

HERSTAD, D.: Intermittent light affects turkey growth and quality. World Poultry, 8 (1992) 8, 50-51

HESTER, P.Y.; SUTTON, A.L.; ELKIN, R.G.:

Effect of light intensity, litter source, and litter management on the incidence of leg abnormalities and performance of male turkeys. Poultry Science, 66 (1987) 4, 666-675 
HULET, R.M.; DENBOW, D.M.; POTTER, L.M.:

Effects of lighting and dietary energy source on male market turkeys. I. Growth performance data. Poultry Science, 72 (1993) 8, 1459-1466

KOVACHISHKI, K.H.; STOIANOV, P.; IORDANOV, I.:

Effects of different lighting regimens in the commercial raising of breeders. Vet Med Nauki., 24 (1987) 4,71-78

LEWIS, P.D.; PERRY, G.C.:

Response of laying hens to asymmetrical interrupted lighting regimens: Physiological aspects. British Poultry Science, 31 (1990) 1, 45-52

LILBURN, M.S.; RENNER, P.A.; ANTHONY, N.B.:

Interaction between step-up versus step-down lighting from four to sixteen weeks on growth and development in turkey hens from two commercial breeds. Poultry Science, 71 (1992) 3, 419-426

MORRISON, D.F.:

Multivariate statistical Methods. Third edition. New York: McGraw-Hill Publ., (1995).

MORRIS, T.R.; BUTLER, E.A.:

New intermittent lighting programme (the reading system) for laying pullets. British Poultry Science, 36 (1995) 4, 531-535

NEWBERRY, R.C.:

Influence of increasing photoperiod and toe clipping on breast buttons of turkeys. Poultry Science, 55 (1992), 1471-1479.

NOLL, S.L.; EL-HALAWANI, M.E.; WAIBEL, P.E.; REDIG, P.; JANNI, K.:

Effect of diet and population density on male turkeys under various environmental condition. 1. Turkey growth and health performance. Poultry Science, 70 (1991) 4, 923-934

RENCHER, A.C.:

Methods of Multivariate Analysis. New York : John Wiley \& sons Publ., (1995)

SENGUL, T.; KONCA, Y.; YILDIZ, A.:

Entansif şartlarda yetiştirilen bronz hindilerde farklı aydınlatma süresinin besi performansı ve karkas özelliklerine etkisi. (Effect of Lighting on Growth Performance and Carcass characteristics of Bronze Turkeys Reared in intensive Conditions). Turk J. Vet. Anim. Sci, 24 (2000), 529-534

SIOPES, T.D.; PARKHURST, C.R.; BAUGHMAN, G.R.:

Intermitted light and growth performance of male turkeys from 2 to 22 weeks of age. Poultry Science, 65 (1986) 12, 2221-2225

SRIVASTAVA, M.S.; CARTER, E.M.:

An introduction to applied multivariate statistics. University of Toronto and University of Guelph., (1983)

SUMMERS, A.R.; ALEXANDER, M.E.; PIZZI, N.J.:

Profile analysis as a discrimination applied to wavelet transformed biomedical spectra. International ICSC Congress on Computational Intelligence: Methods \& Applications, Bangor, Wales, June 19-22, (2001), 54-57

YAHAV, S.; HURWITZ, S.; ROZENBOIM, I.:

The effect of light intensity on growth and development of turkey toms. British Poultry Science, 41 (2000) 1, 101-106

Received: 2004-03-04

Accepted: 2004-12-08

Authors' addresses

Assist. Prof. Dr. MEHMET MENDES (corresponding author)

Assist. Prof. Dr. ALI KARABAYIR

Res. Assist. İ. ERBIL ERSOY

Assist. Prof. Dr. CENGIZ ATAŞOĞLU

Canakkale Onsekiz Mart University Agriculture Faculty Animal Science Department

17020 Canakkale / TURKEY

E-mail: mmendes@comu.edu.tr 